\title{
KEBERADAAN LADY BIKERS DI KOMUNITAS KLUB MOTOR INDONESIA SEBAGAI KORBAN KEJAHATAN KESUSILAAN DI JALANAN
}

\author{
Arya Maulana Pandhu Pradhana \\ Fakultas Hukum Universitas Muhammadiyah Gresik \\ pepe.minot@gmail.com
}

\begin{abstract}
Seeing the Development and growth of one ot the transportation in Indonesia, namely land transportation, it turns out thatit has significantly increased significantly, including the users of motorized vehicles, especially two-wheeled motorbikes (motorbikes). According to Article 28 E paragraph 3 of the 1945 Constitution, everyone has the right to freedom of association, assembly and expression. So that on that basis some people who have the same hobby and passion about motorbikes establish the Motorcycle Club Community Association in Indonesia. Talking about the Motorcycle Club Community reminds us of a bunch of people who like to act arrogant and anarchic on the road when touring. The existence of Lady Bikers is very interesting to discuss, because with their appearance it makes the Negative Stigma (Arrogance and Anarchy) about the Motorcycle Club Community in the eyes of the cloud community become a little dissolved and is expected to be able to color and give a soft I feminine side in the Motorcycle Club Community which generally consists of Men. On the other hand, the presence of Lady Bikers can lead to Decency Crimes on the Street.
\end{abstract}

Keywords : Motorcycle Club Community, Lady Bikers, Decency Crime

\begin{abstract}
ABSTRAK
Melihat perkembangan dan pertumbuhan salah satu transportasi di Indonesia yaitu transportasi darat ternyata sudah sangat jauh meningkat secara signifikan tidak terkecuali dengan para pengguna kendaraan bermotor khususnya roda dua (Sepeda Motor).Menurut Pasal 28 E ayat 3 UUD 1945 bahwa Setiap Orang berhak atas kebebasan berserikat, berkumpul dan menyatakan pendapat. Sehingga atas dasar itu membuat sebagian Orang yang mempunyai hobi dan kegemaran sama tentang Sepeda Motor mendirikan Perkumpulan Komunitas Klub Motor di Indonesia.Keberadaan Lady Bikers menarik sekali untuk di perbincangkan, karena dengan kemunculan mereka membuat Stigma Negatif (Arogan dan Anarki) tentang Komunitas Klub Motor di mata masyarakat awan mejadi sedikit terpupus dan diharapkan dapat mewarnai serta memberi sisi kelembutan/Feminim di dalam Komunitas Klub Motor yang umumnya beranggotakan Para Pria. Di Sisi lain dengan adanya Lady Bikers dapat menimbulkan Kejahatan Kesusilaan atau Pelecehan Seksual di Jalan.
\end{abstract}

\section{Kata Kunci :Komunitas Klub Motor, Lady Bikers, Kejahatan Kesusilaan}




\section{Latar Belakang}

Melihat perkembangan dan pertumbuhan salah satu transportasi di Indonesia yaitu transportasi darat ternyata sudah sangat jauh meningkat secara signifikan tidak terkecuali dengan para pengguna kendaraan bermotor khususnya roda dua (Sepeda Motor). Menurut Data Badan Pusat Statistik jumlah kendaraan bermotor di Indonesia pada tahun 2015 mencapai 121,39 Juta Unit dari angka tersebut yang paling banyak adalah Sepeda Motor dengan jumlah 98,88 Juta unit (81,5\%). Kemudian diikuti oleh Mobil Penumpang dengan jumlah 13,48 Juta unit (11,11\%), selanjutnya Mobil barang dengan jumlah 6,6 Juta unit (5,45 $\%)$ dan Mobil Bus dengan jumlah 2,4 Juta unit (1,99\%) dari total keseluruhan kendaraan ${ }^{1}$. Sehingga dengan keberadaan pengguna sepeda motor yang menempati urutan teratas di mata rantai transportasi darat, akhirnya memunculkan lahirnya Komunitas - komunitas Klub Motor di Indonesia.

Menurut Pasal 28 E ayat 3 UUD 1945 bahwa Setiap Orang berhak atas kebebasan berserikat, berkumpul dan menyatakan pendapat. Sehingga atas dasar itu membuat sebagian Orang yang mempunyai hobi dan kegemaran sama tentang Sepeda Motor mendirikan Perkumpulan Komunitas Klub Motor di Indonesia.

Berbicara tentang Komunitas Klub Motor mengingatkan kita kepada sekumpulan Orang yang suka bertindak Arogan dan Anarki di jalan raya ketika melakukan Touring, belum hilang dari benak kita tentang kasus penganiayaan 2 (dua) Anggota TNI AD di daerah Bukit Tinggi, Padang, Sumatera Barat oleh 5 (lima) Anggota Komunitas Motor HOG (Harley Owner Group) subchapter Bandung, Jawa Barat yang membuat sebagian besar masyarakat awan kurang begitu menerima keberadaan mereka ${ }^{2}$. Meskipun dalam kenyataannya tidak semua Komunitas Klub Motor melakukan tindakan semacam itu. Karena ada juga Komunitas Klub Motor yang memiliki Visi dan Misi untuk melakukan Kegiatan Bakti Sosial di Panti Asuhan dan Panti Jompo serta apabila ada kejadian Bencana Alam melakukan penggalangan dana untuk para korbannya seperti yang telah dilakukan oleh Komunitas Klub Motor DGR (Distinguished Gentleman's Ride) Lady Bikers ${ }^{3}$.

Keberadaan Lady Bikers menarik sekali untuk di perbincangkan, karena dengan kemunculan mereka membuat Stigma Negatif (Arogan dan Anarki) tentang Komunitas Klub Motor di mata masyarakat awan mejadi sedikit terpupus dan diharapkan dapat mewarnai serta memberi sisi kelembutan/Feminim di dalam Komunitas Klub Motor yang umumnya beranggotakan Para Pria. Di Sisi lain dengan adanya Lady Bikers dapat menimbulkan Kejahatan Kesusilaan atau Pelecehan Seksual di Jalan.

\section{Analisa dan Pembahasan}

\footnotetext{
${ }^{1}$ Data Badan Pusat Statistik 2016

2 https://www.tribunnews.com/Azwar Rezi/Kronologi lengkap kasus pengendara Moge aniaya 2 Anggota TNI di Bukit Tinggi, Ini Para Pelakunya/di akses Tanggal 1 Desember 2020

${ }^{3}$ https://www.suara.com/Rossa Vania dan Halidi Risna/DGR Lady Bikers, Komunitas Anak Motor khusus Perempuan Tangguh/di akses Tanggal 1 Desember 2020
} 
Merusak Kesusilaan di hadapan Umum

\section{a. Rumusan KUHP}

KUHP merumuskan pada pasal 281 yang rumusannya sebagai berikut : "Di Hukum dengan hukuman penjara selama-lamanya dua tahun delapan bulan atau denda sebanyakbanyakny atiga ratus rupiah :

1. Barang siapa dengan sengaja merusak kesusilaan dihadapan umum

2. Barang siapa dengan sengaja merusak kesusilaan di muka orang lain yang hadir dengan tidak kemauannya sendiri.

Rumusan KUHP tersebut direncanakanakan disempurnakan dengan RUU KUHP 1993 pada pasal 377 (14.01) yang bunyinya sebagai berikut :Dipidana dengan pidana paling lama satu tahun atau denda paling banyak kategori III :

Ke-1 barang siapa melanggar kesusilaan di hadapan umum.

Ke-2 barang siapa melanggar kesusilaan di muka orang lain, yang hadir tanpa kemauan sendiri ${ }^{4}$.

Pada dasarnya rumusan KUHP dan rumusan RUU KUHP, tidak berbeda kecuali unsur dolus (sengaja), sedang ancaman/pidana jauh berbeda.Tidak jelas apa yang menjadi pertimbangan sehingga ancaman pidana tersebut jauh berbeda sedang denda naik dari Rp. 300,- (tigaratus rupiah) menjadi Rp. 3.000.000,- (tiga juta rupiah). Secara rasional perubahan demikian dapat terjadi jika :

1. Delik tersebut telah menurun

2. Delik tersebut tidak menimbulkan kerugian yang begitu besar lagi bagi masyarakat.

3. Perumus RUU KUHP cenderung untuk menjatuhkan hukuman denda ${ }^{5}$

b. Pengertian merusak kesusilaan

Perkataan merusak kesusilaan dijelaskan Mr. J.M. Van Bemmelen antara lain sebagai berikut : Pelanggaran kehormatan kesusilaan di muka umum ialah terjemahan dari outrage public a la pudeur dalam pasal 33 Code Penal. Ini dapat ditafsirkan sebagai tidak ada kesopanan di bidang seksual.Jadi sopan ialah tindakan atau tingkah laku untuk apa seorang tidak usah malu apabila orang lain melihatnya atau sampai mengetahuinya dan juga oleh karenanya orang lain itu umumnya tidakakan terperanjat apabila melihat atau sampai mengetahuinya. Jadi Malu atau terperanjat merupakan hal yang paling menentukan dalam menafsirkan tidak ada kesopanan di bidang seksual ${ }^{6}$.

\section{c. Pengertian di muka umum}

\footnotetext{
${ }^{4}$ Marpaung Leden, 2004, Kejahatan Terhadap Kesusilaan, Jakarta, Sinar Grafika

5 Ibid Hal 32

${ }^{6}$ Ibid Hal 33
} 
Pada penjelasan resmi pasal 377 (14.01) RUU KUHP dimuat pengertian di muka umum antara lain sebagai berikut : Kata di muka umum dalam pasal ini menunjuk kepada dapat dilihatnya perbuatan itu oleh orang lain. Kemungkinan dapat dilihatnya perbuatan itu oleh orang lain merupakan suatu ciri dari tindak pidana ini ${ }^{7}$.

Penampilan Lady Bikers di Komunitas Klub Motor ketika melakukan Touring sering terlihat berbeda dengan anggota-anggota lainnya hal inilah yang menjadi pemicu terjadinya Kejahatan Kesusilaan di jalanan. Bentuk Kejahatan Kesusilaan di jalanan ada bermacam macam seperti uraian di bawah ini :

1. Lirikan yaitu ketika Pelaku (Pengendara Motor lainnya) yang sedang berpapasan dengan Korban (Lady Bikers) melakukan lirikan dengan tatapan tidak senonoh.

2. Bersiul yaitu ketika Pelaku (Pengendara Motor lainnya) yang sedang berpapasan dengan Korban (Lady Bikers) mengeluarkan siulan dari mulutnya dan biasanya ditujukkan untuk melecehkan bagian-bagian tertentu dari tubuh Korban (Lady Bikers) tersebut.

3. Mengeluarkan suara ciuman yaitu ketika Pelaku (Pengendara Motor lainnya) yang sedang berpapasan dengan Korban (Lady Bikers) mengeluarkan kata Emuah dengan menggerakkan tangan mencium bibirnya sendiri tepat di depan wajah Korban (Lady Bikers) ketika melintas di depannya.

4. Menguntit yaitu ketika Tersangka (Pengendara Motor lainnya) mengikuti dari belakang secara sengaja dengan tujuan tidak baik yang tanpa disadari oleh Korban (Lady Bikers).

5. Memegang yaitu ketika Pelaku (Pengendara Motor lainnya) melakukan tindakan dengan sengaja dan sadar memegang bagian Vital tubuh dari Korban (Lady Bikers).

Adapun Kejahatan Kesusilaan diatur pada Bab XIV KUHP yang terdiri dari Pasal 281 sampai dengan Pasal 303 dan umumnya Kejahatan Kesusilaan di Jalanan ini akan menimbulkan keresahan, kecemasan dan dampak psikologis yang mendalam bagi korban sehingga Lady Bikers sebagai Korban dari tindakan ini akan trauma untuk melakukan kegiatan Touring bersama Komunitas Klub Motornya.

Delik ini paling banyak menimbulkan kesulitan dalam penyelesainnya baik pada tahap penyidikan, penuntutan maupun pada tahap pengambilan keputusan.Selain kesulitan dalam batasan juga kesulitan pembuktian misalnya perkosaan atau perbuatan cabul yang pada umumnya dilakukan tanpa kehadiran orang lain $^{8}$.

Sehingga agar para Lady Bikers dapat terhindar dari segala bentuk Kejahatan Kesusilaan di Jalanan maka ada beberapa hal yang harus diperhatikan dan dilakukan yaitu sebagai berikut :

1. Gunakan Baju yang sopan dan Aksesoris tidak mencolok serta berlebihan ketika akan melakukan kegiatan Touring dengan Komunitas Klub Motornya.

\footnotetext{
7 Ibid Hal 35

8 Ibid Hal 31
} 
2. Peran Aktif Anggota lainnya (Anggota yang Laki-laki) untuk mengawasi pergerakan para Lady Bikers ketika Touring sangat menentukan untuk meminimalisir terjadinya hal-hal yang tidak di inginkan di jalan.

3. Kenalilah jenis - jenis kejahatan kesusilaan agar nanti ketika terjadi di jalan sudah siap untuk mengantisipasinya.

4. Berani untuk melakukan tindakan perlawanan terhadap pelaku dengan cara memarahi secara langsung ketika kejadian berlangsung kemudian berteriak untuk memancing masyarakat sekitar merespon kejadian tersebut dan terakhir segera melapor ke Pihak berwajib.

5. Berani untuk berbicara dan berbagi di Media Sosial (Facebook, Twitter, Instagram dll). Semakin banyak sharing dan viral cerita tersebut di Media Sosial maka diharapkan banyak masyarakat yang simpati dan peduli sehingga kasus kejahatan kesusilaan di jalanan menjadi atensi lebih dari Pihak berwajib dalam hal ini adalah Kepolisian.

Ingat kejahatan terjadi bukan hanya Karena ada niat dari pelakunya, akan tetapi juga karena adanya kesempatan ${ }^{9}$. Jadi tetap waspada di setiap situasi dan kondisi agar terhindar dari segala bentuk kejahatan.

\section{Kesimpulan}

Berdasarkan analisa dan pembahasan tersebut diatas maka dapat disimpulkan bahwa ada beberapa hal yang dapat menjauhkan kita dari Segala bentuk Perbuatan Kejahatan yaitu :

1. Meningkatkan kualitas Keimanan dan Ketaqwaan kita kepada Tuhan YME maka dapat menghindarkan kita dari perbuatan - perbuatan yang tidak baik.

2. Membatasi diri untuk tidak menonton Film yang mengandung unsur serta adegan Kekerasan dan Seksualitas.

3. Memperbanyak Ibadah sesuai dengan Agama dan keyakinannya masing - masing.

4. Aktif mengikuti kegiatan Keagamaan di lingkungan tempat kita tinggal.

5. Menyibukkan diri dengan berbagai aktivitas Sosial dengan Komunitas terkait dan Masyarakat sekitar.

Semoga kita semua dapat terhindar dari perbuatan - perbuatan yang tidak baik dan semoga kita semua bisa menjadi orang yang berguna dan bermanfaat bagi lingkungan sekitar kita.

\footnotetext{
${ }_{9}^{9}$ Pesan (Alm) RM Arie Hendrosaputro Pemeran Bang Napi sebagai Pengisi Segmen Program acara Sergap RCTI
} 


\section{Daftar Pustaka}

\section{Buku}

Marpaung Leden, 2004, Kejahatan Terhadap Kesusilaan, Jakarta, Sinar Grafindo.

Bemmelen, J.M Van. 1986, Hukum Pidana 1, Hukum Pidana 2, Hukum Pidana 3, Bandung, Bina Cipta.

\section{Wesite}

https://www.tribunnews.com/Azwar Rezi/Kronologi lengkap kasus pengendara Moge aniaya 2 Anggota TNI di Bukit Tinggi, Ini Para Pelakunya/di akses Tanggal 1 Desember 2020.

https://www.suara.com/Rossa Vania dan Halidi Risna/DGR Lady Bikers, Komunitas Anak Motor khusus Perempuan Tangguh/di akses Tanggal 1 Desember 2020.

\section{Daftar Peraturan Perundang-undangan}

Undang - Undang Dasar Negara Republik Indonesia Tahun 1945 